\title{
Disabled Children in Public Playgrounds: A pilot study
}

\section{Seyed Hassan Khalifeh Soltani, Mohamed Yusoff Abbas, Mohamad Awang}

\author{
Faculty of Architecture Planning and Surveying, \\ Universiti Teknologi MARA, Shah Alam, Malaysia. \\ Hassan_kh8@yahoo.com
}

\begin{abstract}
This is a cross-sectional pilot study on children with disabilities needs in public playgrounds. They often faced problems at public playgrounds, entertainment and amusement areas, due to the lack of ample provisions to cater their special needs. The purpose of the study was to inuestigate the current status of infrastructure and design proper public playgrounds in Malaysia. 7he study period was six months. Ouerall 40 disabled children, parents, teachers and doctors were questioned and interuiewed. Statistical Package for the Social Science (SPSS) software program was used for analysis. 7he ßnding reuealed that there is necessary need to improue and construct well equipped public playgrounds for children with disabilities.
\end{abstract}

Keywords: disabled children; public playgrounds; post-occupancy study; quality of life.

eISSN ISSN 2514-751X @ 2018. The Authors. Published for AMER ABRA CE-Bs by e-International Publishing House, Ltd., UK. This is an open-access article under the CC BY-NC-ND license (http://creativecommons.org/licenses/by-nc-nd/4.0). Peer-review under responsibility of AMER (Association of Malaysian Environment-Behaviour Researchers), ABRA (Association of Behavioural Researchers on Asians) and cE-Bs (Centre for Environment-Behaviour Studies), Faculty of Architecture, Planning \& Surveying, Universiti Teknologi MARA, Malaysia.

DOI: https://doi.org/10.21834/aje-bs.v3i6.238 


\subsection{Introduction}

Children need a place to play and they also need space with informality, and freedom to move around and make noises. They should express themselves through experiment and investigate the world around. Disabled children need this freedom even more than others. In surroundings which stimulate their imagination and challenge them to face and overcome risks, they will be given opportunities to build their self confidence and independence.

According to the UN statistics (2006), more than 500 million people in the whole world have different disabilities. In 1992, Euro stat showed that $11 \%$ of the European population had different disabilities (Anonymous 3, 2003). The situation is nearly the same in Malaysia. According to the World Health Organization (WHO), children with disabilities could be defined as any child unable to ensure by himself wholly or partly, the necessities of a normal individual and or social life, as a result of a deficiency either congenital or not, in his physical or mental capabilities. The WHO also stated that $10 \%$ of the population in each country around the world has people with disabilities. It has been estimated that among the $10 \%$ of the population with disability, one third are among children less than 15 years old, estimating into the Malaysian population of 27 million there are about 900,000 children less than 15 years old with different disabilities which they require special care and facilities in public areas.

In most parts of the developed world, they used differentassessment tools has been used to describe the developmental achievement among disabled children. However, most of the studies concentrate on one particular disability of children and one particular skill area. In Malaysia, there has been no study in to needs of proper public playgrounds among children with disability. This research into the public provision of playgrounds in Malaysia for children with disabilities was focused on the facilities promoting the disabled child's right to play with normal children. It particularly helps the voluntary organizations and community groups to fathom the problem in a new light. The research will also help them understand these issues better and fund further research. The scheme aims to build the research capacity of such groups; to broaden and deepen knowledge of specific disability issues; and to inform policy makers and service deliverers of disability needs and issues.

\section{The main objectives of this research were in three folds:}

1. To identify possible design faults or the lack of provisions for the disabled children in public playgrounds.

2. To identify possible reasons that could have caused such situation.

3. To suggest ways and means in improving the situation.

Any discussion regarding play and children with disabilities cannot ignore the nature of the play itself, the changing patterns of play and trends and directions of childhood today. Firstly, the nature of play and the changing patterns of play were discussed in Webb (1999) and it is useful to mention these again briefly in the context of playground designed for children with disabilities.

It has long been established that outdoor play has developmental and therapeutic benefits for children. It is fun, helps to keep children healthy, helps develop an awareness of risk and danger and is important for building social, emotional and life skills. The most diverse 
the natural and physical surroundings in an outdoor play space, the greater range of learning and developmental opportunities (Potter, 2001, 2002). Consideration should always be given at the earliest stages of developing a play environment to the different needs of its potential users. Design of the play environment, both physical and organizational, should ensure that disabled children can access the play opportunities alongside other children from the community.

The Disability Convention is an agreement to help make sure that those children and adults with disabilities are treated fairly and can equally participate in all aspects of life. The rights in the Disability Convention are not new. They are the human rights for all children and adults. The Disability Convention is needed to guarantee that these rights are respected for persons with disabilities (UNICEF, 2007). Social barriers such as fear, embarrassment or discriminatory attitudes also need to be tackled so that an accessible play space is also an inclusive one in which disabled children and theirfamilies feel welcome. The good practice guide provides examples of how careful attention to design can help to ensure that play spaces are inclusive, comfortableand appealing to disabled childrenand theirfamilies. The issues to review fall into two broad categories (i) social issues and (ii) technical and physical factors. Reviewing social issues involves thinking about how to create opportunities for disabled and non disabled children to play together.

For disabled children and their families who are often not visible in communities, there are many benefits to being involved in consultation. Inclusion in consultation processes is often valued in itselfasitraises the self confidence of individuals and groups and affirms entitlement as community members and organizations. Parents of disabled children report that being consulted about the nature of a play space and involved in its development is one of the factors which increase the likelihood that they will take their children there(ODPM, 2002, 2003).

The UN Convention on the Rights of the Child states that disabled children have the right to be included in their local community and to do the kinds of things that non disabled children do. They have the right to take part in play and leisure activities, the equal right to access cultural, artistic and leisure opportunities and the right to support to help them do this (UN Convention on the Rights of the Child, Article 23(1), (3); Article 31; Children Act 1989, Schedule 2, Paragraph 6 and 8).

In this particular research, there were several methods of data collection employed during research process. These included: A review of the relevant literature, Invited comments and observations from children and their parents, an access audit of randomly selected playgrounds, using the audit developed by the Royal Society for the Prevention of Accidents (RoSPA) in the UK, Visits selected playgrounds and organizations to gain an understanding of best practice in this regard. Many responses were around the theme that there was a limited ability to enter into play due to decreased mobility, decreased motor function, sensory impairments and those perceptual, cognitive and socio emotional difficulties reduced interactions. Poor access to playgrounds and the lack of wheelchair access to play equipment was mentioned by seven respondents. The lack of supervision in playgrounds was also mentioned. One parent said that access to playgrounds and play equipment was not a problem but, that play then tended to be repetitive on particular items. The attitude of other children and parents was mentioned by one respondent. 


\subsection{Methodology}

The research was intended to use quantitative data to find the values in numerical forms so that the statistical analysis was performed, used questionnaires. The study was also used interviewsand observation methods as qualitative methodology supportive of action research. The research method covered the followings: i) intensive literature reviews on the children playgrounds with definition on disable children, playgrounds facilities and any related materials to the subject matter: ii), Site visits to review public playgrounds in Klang valley for examining the current situation and facilities provided and iii) site visit to various public playgrounds for the disable children.

Data collected was based on site visits and personal observations, questionnaires, and interviews upon the disabled children, their parents, teachers and the doctors involved in institutes, universities and hospitals for special children. The 37 respondents were chosen from three different institutes, including Tasputra, Perkim, Wisma and Harapan where the researcherdistributed the questionnaire to the disabled childrentheirparents and teachers. The researcher also visited the KPJ Shah Alam specialist hospital where the questionnaire were distributed amongst the specialized doctors of the related field Statistical Package for the Social Science (SPSS) software program was used for the data analysis.

The three methods of triangulation used in this research are questionnaire, interview and observation method. For the three methods of triangulation, it was intended to explore the policy, point of views and decision of people involved in providing equipments for public playgrounds (Used interview). Second to explore the opinions and impressions of people involved in using the public playgrounds (Used questionnaire). The data collected from interviews and field surveys was fully analyzed and the finding was fully discussed for recommendation.

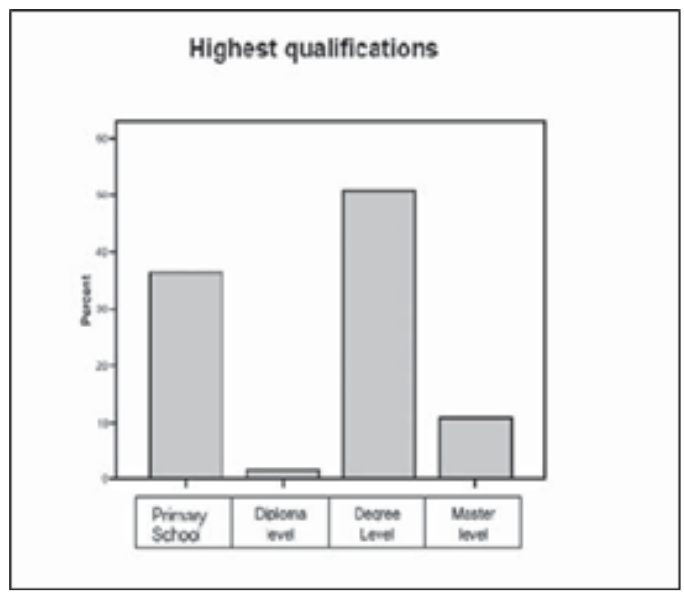

Figure 1: Respondents Highest Qualifications 


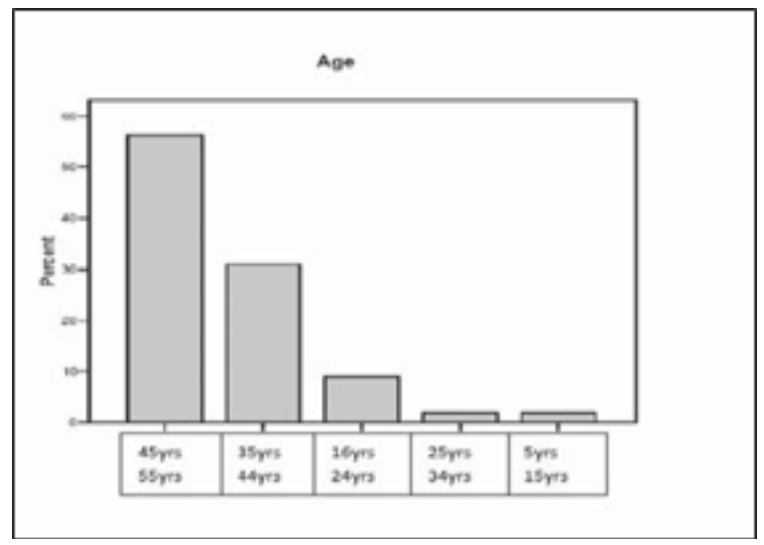

Figure 2: Respondents Age

Out of the total of 37 respondents, $65 \%$ were females while the remaining $35 \%$ were male. Most of the respondents for this research are between the ages of 45 years to 55 years contributing to a percentage of $56 \%$. The lowest age groups are between 5 years to 15 years and 25 years to 34 years with a percentage of $2 \%$ from both groups while respondents between the ages of 35 years to 44 years constitute of $31 \%$ and those in between 16 years to 24 years contribute to $9 \%$. From the total of 37 respondents, the highest qualifications groups come from the degree level constituting a percentage of $51 \%$ and the lowest qualifications groups come from the diploma level with a percentage of $2 \%$. Respondents from primary School constitute of $36 \%$ planning that now they are pursuing their degree course. The rest $11 \%$ are those from the master level who are now pursuing their doctoral course.

Table 1: Result of Section 2 questionnaire

\begin{tabular}{|c|c|c|c|c|c|c|c|c|c|c|c|}
\hline Question & \begin{tabular}{|l|} 
Strongly \\
Disagree
\end{tabular} & Disa & gree & & $\begin{array}{l}\text { either } \\
\text { ee Nor } \\
\text { agree }\end{array}$ & Agr & & $\begin{array}{l}\text { trong } \\
\text { Agre }\end{array}$ & & \begin{tabular}{|c|} 
Total \\
requency
\end{tabular} & $\begin{array}{c}\text { Total } \\
\text { Percent }\end{array}$ \\
\hline $\begin{array}{l}\text { he current status of } \\
\text { playground is inclusive of } \\
\text { disabled children. }\end{array}$ & $1437.8 \%$ & 15 & $40.5 \%$ & 2 & $5.4 \%$ & 1 & $2.7 \%$ & 5 & $13.5 \%$ & 37 & $100 \%$ \\
\hline $\begin{array}{l}\text { hese playgrounds need } \\
\text { more facilities, infrastructure } \\
\text { and design changes. }\end{array}$ & $0 \%$ & 0 & $0 \%$ & 0 & $0 \%$ & 19 & $51.4 \%$ & 18 & $48.6 \%$ & 37 & $100 \%$ \\
\hline $\begin{array}{l}\text { he facilities in the public } \\
\text { playgrounds are standardized. }\end{array}$ & $8.1 \%$ & 6 & $16.2 \%$ & 9 & $24.3 \%$ & 15 & $40.5 \%$ & 4 & 10.8 & 37 & $100 \%$ \\
\hline $\begin{array}{l}\text { his will create awareness } \\
\text { among other society to treat } \\
\text { such childrenequally. }\end{array}$ & $0 \%$ & 5 & $13.5 \%$ & 2 & $5.4 \%$ & 13 & $35.1 \%$ & \begin{tabular}{|l|l}
0 & 17
\end{tabular} & 45.9 & 37 & $100 \%$ \\
\hline
\end{tabular}




\begin{tabular}{|l|r|r|r|r|r|r|r|r|r|r|r|r|}
\hline $\begin{array}{l}\text { he design of the playground } \\
\text { should not be discriminatory. }\end{array}$ & $2.7 \%$ & 1 & $2.7 \%$ & 1 & $2.7 \%$ & 22 & 59.5 & 12 & $31.6 \%$ & 37 & $100 \%$ \\
\hline $\begin{array}{l}\text { he present playgrounds are } \\
\text { in sufficientnumbers for } \\
\text { children with disability. }\end{array}$ & $18.9 \%$ & 5 & $13.5 \%$ & 1 & $2.7 \%$ & 15 & $40.5 \%$ & 9 & 24.3 & 37 & $100 \%$ \\
\hline $\begin{array}{l}\text { he current status of } \\
\text { playground accommodates the } \\
\text { physical needs of the } \\
\text { disabled children at play. }\end{array}$ & $1232.4 \%$ & 20 & $54.1 \%$ & 3 & $8.1 \%$ & 2 & $5.4 \%$ & 0 & $0 \%$ & 37 & $100 \%$ \\
\hline
\end{tabular}

In the table above the result is related to the second section of the questionnaire, which the respondents agree that the public playgrounds are not inclusive of disabled children, there are no public playgrounds specially designed for children with disabilities. The design of public playgrounds should not be discriminatory.

Table 2: Result of Section 3 questionnaire

\begin{tabular}{|c|c|c|c|c|c|c|c|c|c|c|c|}
\hline \multirow{2}{*}{\begin{tabular}{|l|}
\multicolumn{1}{|c|}{ Question } \\
lasthegovernmentto play any \\
role in funding such changes in \\
public playgrounds.
\end{tabular}} & \begin{tabular}{|l|} 
Strongly \\
Disagree
\end{tabular} & \multicolumn{2}{|c|}{ Disagree } & \multicolumn{2}{|c|}{$\begin{array}{l}\text { Neither } \\
\text { Agree Nor } \\
\text { Disagree }\end{array}$} & \multicolumn{2}{|c|}{ Agree } & \multicolumn{2}{|c|}{$\begin{array}{l}\text { trongly } \\
\text { Agree }\end{array}$} & \multirow{2}{*}{\begin{tabular}{|c|}
$\begin{array}{c}\text { Total } \\
\text { requency }\end{array}$ \\
37
\end{tabular}} & \multirow{2}{*}{\begin{tabular}{|r|}
$\begin{array}{c}\text { Total } \\
\text { Percent }\end{array}$ \\
$100 \%$ \\
\end{tabular}} \\
\hline & $2.7 \%$ & 2 & $5.4 \%$ & 3 & $8.1 \%$ & 18 & $48.6 \%$ & 13 & $35.1 \%$ & & \\
\hline $\begin{array}{l}\text { las the government taken any } \\
\text { action for the protection of } \\
\text { children with disability. }\end{array}$ & $5.4 \%$ & 8 & $21.6 \%$ & 10 & $27 \%$ & 17 & $45.9 \%$ & 0 & $0 \%$ & 37 & $100 \%$ \\
\hline $\begin{array}{l}\text { Should the government and } \\
\text { community ensure tha } \\
\text { specialized service providers } \\
\text { are to design such } \\
\text { playgrounds. }\end{array}$ & $0 \%$ & 0 & $0 \%$ & 1 & $2.7 \%$ & 22 & $59.5 \%$ & 14 & $37.8 \%$ & 37 & $100 \%$ \\
\hline $\begin{array}{l}\text { Hovernment decisions } \\
\text { regarding disabled children } \\
\text { should be based on } \\
\text { knowledge about their } \\
\text { special needs in public } \\
\text { playgrounds. }\end{array}$ & $0 \%$ & 0 & $0 \%$ & 0 & $0 \%$ & 17 & $54.9 \%$ & 20 & $54.1 \%$ & 37 & $100 \%$ \\
\hline $\begin{array}{l}\text { he laws and rules that are set } \\
\text { in a countrybyits government } \\
\text { fully protect the rights of } \\
\text { children with disabilities. }\end{array}$ & $0 \%$ & 8 & $21.6 \%$ & 8 & $21.6 \%$ & 12 & $32.4 \%$ & 9 & $24.3 \%$ & 37 & $100 \%$ \\
\hline $\begin{array}{l}\text { s there any regulation } \\
\text { binding the designer to } \\
\text { accommodate the needs of } \\
\text { disabled children. }\end{array}$ & $18.9 \%$ & 5 & $13.5 \%$ & 1 & $2.7 \%$ & 15 & $40.5 \%$ & 9 & $24.3 \%$ & 37 & $100 \%$ \\
\hline
\end{tabular}

In the second table, shown the result of the third section of the questionnaire where the respondents were asked questions regarding the role of government and society in facilitating the needs of disabled children in playgrounds, most of the respondents agree that 
the role of government and society is not enough to facilitate the needs of disabled children at public playgrounds. In response to the fourth part of the questionnaire, the respondents agree that the current design of public playground do not attracted children with disabilities, and the well designed play ground can defiantly improve the social skills and confidence level of disabled children.

All the data collected from the three methods of triangulation which include questionnaire, interview and observation were analyzed. Referring to the literature review the analysis shows that there is an immense need to improve the current design and status to facilitate the needs of disabled children. The analysis shows that nature possess a healing power and allowing disabled children to play in public playground along with normal children, can boost up their confidence level. Results analysed and discussed in relation to literature reviewed to found out that the respondents agree that the public play ground is not inclusive of disabled children, there are no public play grounds specially designed for children with disabilities. The public play grounds need more facilities and upgrading to accommodate the disabled children. The present public play grounds do not accommodate the special needs of disabled children. The design of public play grounds should not be discriminatory.

According to the first research question of the questionnaires distributed, the researchers found that the majority of the respondents do agree with the questions that no public playgrounds are inclusive of disabled children and others. Comparing to the literature review the researcher found that the respondent's answers support the literature review on the first research question Measuring the existing facilities and suitableequipment for disabled children in public parks (potter, 2002 \& Dunn et al, 2003).

The researcher also found out that the respondents agree to the first research question and that the firstresearch question is justified. Concerning the role of the governmentin this issue were also justified by the respondents as the respondents support the second research question. The third research question also is justified as the respondents agree with the third research question.

\subsection{Conclusion}

Every child in the world looks different and has different ideas, experience, traditions and abilities. These differences create new possibilities, new hopes, new dreams and new friendships. The differences among the people of the world are a treasure for all to appreciate and share. Each child is part of the world family and contributes own unique abilities. The results of this research showed that facilities in the public play grounds are not enough to accommodate children with special needs. The facilities of the modern day public parks are not standardized. It emphasizes to increase government and NGO funding to create well equipped public parks which accommodate the needs of children with disability. It also stated that government decisions regarding disabled children should be based on knowledge about their special needs in public play grounds. In this research, it has been shown that the current design of playground do not attract the children with disabilities and the concept of modern day public play ground does not satisfy their needs. It has also advised that the design of the public play ground should not be discriminatory, and the play ground should accommodate the 
physical needs of disabled children. Based on this research the researcher recommends that proper building regulations are unavoidable. Community awareness is necessary to help disabled children. Designers and builders should keep the disabled children needs when providing public facility such as play areas. There is enough room to research this sensitive area. The researcher recommends a full length study on the existing availability of public parks in Selangor area. A detailed research is recommended on the disability factor and provision of recreational facilities in Klang valley. Also, the impact of properly designed playgrounds for disabled children should be studied.

\section{Acknowledgement}

The authors present the deepest thanks to a number of people who helped and supported the project during the writing of this research. I would also extend my thanks to Tasputra, Perkim, Wisma and Harapan institutions without whom this project would have been a distant reality.

\section{References}

Anonymous3. (2003). Available at http://www.mpm.org.tr/Docs/03_OZURLULER\%20TURIZMI.pdf (accessed 25 August 2010).

Bogdan,R.C., \&SariKnopp,B.(2007). Qualitative researchforeducation: An introduction to theories and methods (5th ed.).

Dattner, R. (1969).Design forPlay. The MITPress, cambridge, massachuse.

Do"kmeci, V., \& Berko"z, L. (1994). Transformation of Istanbul's CBD from a monocentric to a polycentric city. European PlanningStudies, 2(2), $193-205$.

Dunn, K., Moore, M., \& Murray, P. (2003). Best Practice in Inclusive Out of School Provision. London, Kidsactive.

Fiske, D., W, Campbell, \& Donald, T. (1959). Convergent and discriminant validation by the multitrait mutimethod matrix." Psycho logical Bulletin. 56, 81 - 105.

Gant, R. (1997). Pedestrianisation and disabled people:A study of personal mobility in Kingston town centre. Disability and Societ. 12(5), $723-740$.

Gould, S. J. (1996). Full House: The spread of excellence from Plato to Darwin. Harmony Books. . New York.

Huttenlocher,P.R.(1990). MorphometricStudy ofHumanCerebralCortex Development. Neuropsychological, 28(6).

Huttenlocher, P. R. (1992). Neural Plasticity, in Asbury, McKhann and McDonald (eds). Diseases of the Nervous System. 1, $63-71$.

Lewin , K. (1946). Action Research and Minority Problems. Journal of Social Issues, 2, 34 - 46.

NPFA, C. s. P. C. p. I. B. P. (2000). what play provision should do for children. London: . 
Soltani, S.H.K., et.al. / Asian Journal of Environment-Behaviour Studies (ajE-Bs), 3(6) Jan / Feb 2018 (p 81-89)

ODPM, O. o. t. D. P. M. (2002). Living Places: Cleaner, Safer, Greener.

London, ODPM.

ODPM, O. o. t. D. P. M. (2003). Sustainable Communities: Building for the Future. London, ODPM

Oliver,M.(1996).1nderstandingDisability?Fromtheorytopractice.Retrieved from

http://www.brainhe.com/TheSocialModelofDisabilityText.html 